\title{
The important effect of 5-HTTLPR polymorphism on the risk of depression in patients with coronary heart disease: a meta-analysis
}

Li-Jun Zhang ${ }^{1+}$, Xian-Tao Zeng ${ }^{2,3+}$, Ming-Juan Zhao ${ }^{2,4}$, Dong-Fang He ${ }^{1}$, Jian-Yang Liu ${ }^{1}$ and Mei-Yan Liu*

\begin{abstract}
Background: Depression has been recognized as an independent risk factor of coronary heart disease (CHD). Moreover, there is interrelationship of both depression and CHD. However, the potential pathophysiological mechanisms remain unknown. It might be influenced by genetic and environmental factors. According to recent researches, there is potential association between serotonin transporter gene-linked polymorphic region (5-HTTLPR) polymorphism and risk of depression in CHD patients, but the results are still inconclusive. Therefore, we performed this meta-analysis based on unadjusted and adjusted data to ascertain a more precise conclusion.
\end{abstract}

Methods: We searched relevant articles through PubMed, Embase, Web of Science, Chinese BioMedical Literature (CBM) and Chinese National Knowledge Infrastructure (CNKI) databases up to August 26, 2019. Study selection and data extraction were accomplished by two authors independently. The strength of the correlation was assessed via odds ratios (ORs) with their 95\% confidence intervals (95\%Cls).

Results: This meta-analysis enrolled six observational studies. Based on unadjusted data, there was significant relationship between 5-HTTLPR polymorphism and depression risk in CHD patients under all genetic models (S vs. $L: O R=1.31,95 \% \mathrm{Cl}=1.07-1.60 ; \mathrm{SS}$ vs. $\mathrm{LL}: \mathrm{OR}=1.73,95 \% \mathrm{Cl}=1.12-2.67 ; \mathrm{LS}$ vs. $\mathrm{LL}: \mathrm{OR}=1.47,95 \% \mathrm{Cl}=1.13-1.92 ; \mathrm{LS}+$ SS vs. $L L: O R=1.62,95 \% \mathrm{Cl}=1.25-2.09 ; \mathrm{SS}$ vs. $\mathrm{LL}+\mathrm{LS}: \mathrm{OR}=1.33,95 \% \mathrm{Cl}=1.02-1.74)$. The results of adjusted data further strengthened this relationship (SS vs. $\mathrm{LL}: \mathrm{OR}=1.89,95 \% \mathrm{Cl}=1.28-2.80 ; \mathrm{LS}$ vs. $\mathrm{LL}: \mathrm{OR}=1.69,95 \% \mathrm{Cl}=1.14-2.51$; $L S+S S$ vs. $L L: O R=1.80,95 \% C l=1.25-2.59)$. Subgroup analyses based on ethnicity and major depressive disorder revealed similar results to that of the overall analysis. No evidence of publication bias was observed.

Conclusions: Our results suggest that 5-HTTLPR polymorphism may have an important effect on the risk of depression among patients with CHD, and carriers of the $S$ allele of $5-H T T L P R$ are more vulnerable to depression.

Keywords: 5-HTTLPR polymorphism, Depression, Coronary heart disease, Meta-analysis

* Correspondence: liumeiyanaz@163.com

'Li-Jun Zhang and Xian-Tao Zeng contributed equally to this work. 'Department of Cardiology, Beijing Anzhen Hospital Affiliated to Capital Medical University, No. 2 Anzhen Road, Chaoyang District, Beijing 100029, China

Full list of author information is available at the end of the article

\section{Background}

Depression has taken a pivotal place in contributing to coronary heart disease (CHD), what's worse, the comorbidity accounts for an increasing trend of mortality [1-4]. There is no reason to ignore its threat to human health. However, the comorbidity is regarded as interdisciplinary science that associates psychology, psychiatry, neurology

(c) The Author(s). 2020 Open Access This article is licensed under a Creative Commons Attribution 4.0 International License, which permits use, sharing, adaptation, distribution and reproduction in any medium or format, as long as you give appropriate credit to the original author(s) and the source, provide a link to the Creative Commons licence, and indicate if changes were made. The images or other third party material in this article are included in the article's Creative Commons licence, unless indicated otherwise in a credit line to the material. If material is not included in the article's Creative Commons licence and your intended use is not permitted by statutory regulation or exceeds the permitted use, you will need to obtain permission directly from the copyright holder. To view a copy of this licence, visit http://creativecommons.org/licenses/by/4.0/ The Creative Commons Public Domain Dedication waiver (http://creativecommons.org/publicdomain/zero/1.0/) applies to the data made available in this article, unless otherwise stated in a credit line to the data. 
and cardiology, which increases complexity and difficulty of revealing the underlying mechanisms. According to the related researches, the potential mechanisms involve the dysfunction of hypothalamus-pituitary-adrenal aixs, dysregulation of sympathetic and parasympathetic nerves system, dysmodulation of special neurotransmitters or hormones likely serotonin (5-HT), adrenalin $[5,6]$.

Notably 5-HT, it could be considered as a good communicator between central nervous system (CNS) and peripheral system, due to its signal transporting role in CNS transduction when releasing by presynapic vesicles, and its vasoconstricting and vasodilating role in periphery when releasing by platelets [7]. Then we must mention another vital factor - 5-HT transporter (5-HTT) which is responsible for the reuptake of 5-HT and regulates the balance of intracellular and extracellular 5-HT. 5-HTT is a kind of transmembrane protein belonged to solute carrier family, and encoded by SLC6A4 gene localised in chromosome 17q11.1-q12 [8]. Moreover, the 5-HTT gene-linked polymorphic region (5-HTTLPR) polymorphism has achieved particular attention, owing to its direct role in influencing the transcriptional activity of SLC6A4 gene. 5-HTTLPR polymorphism involves allele deletion (the short allele, $\mathrm{S}$ allele) and allele insertion (the long allele, $\mathrm{L}$ allele). $\mathrm{S}$ allele is demonstrated to have lower transcriptional activity than $\mathrm{L}$ allele, resulting in the reduction of 5-HTT in the cell membrane $[9,10]$. Consequently, the reduction of 5-HTT causes the imbalance of 5-HT concentration and function, which is believed to be one of the important causation of depression and accelerates the progress of CHD $[9,10]$.

Several individual studies have conducted on the association of 5-HTTLPR and depression in CHD patients. For instance, Nakatani et al. [11] indicated that $S$ allele was related with depressive symptoms in patients with acute myocardial infarction (AMI), otherwise, they found $\mathrm{S}$ allele was correlated with cardiac events in the followup study. While different conclusions were elucidated in both Cao [12] and Bozzin's [13] researches. In order to have a comprehensive understanding of the relation between 5-HTTLPR and depression in CHD patients, we performed this meta-analysis and subgroup analysis according to race and major depression (MD).

\section{Methods}

We performed this meta-analysis according to the requirements of PRISMA (Preferred Reporting Items for Systematic Reviews and Meta-Analyses) [14]. There was no need for ethical approval. We had registered in PROSPERO for this meta-analysis, and the number was CRD42017074196.

\section{Eligibility criteria}

Studies would be selected according to the following criteria: (1) Patients with established CHD, combined with depression in case group, contrarily in control group; (2) 5-
HTTLPR had been detected; (3) Cohort, case-control or cross-sectional study; (4) English or Chinese language; (5) Data were eligible to extract and full-texts could be found. If two or more studies involved the same population, we would select the one with most recent or complete study.

\section{Search strategy}

Articles published before August 26, 2019, were collected from PubMed, Embase, Web of Science, Chinese BioMedical Literature (CBM) and Chinese National Knowledge Infrastructure (CNKI) databases. Search terms: (coronary disease OR myocardial infarction OR coronary heart disease OR CHD OR acute coronary syndrome OR coronary artery disease) AND (depression OR depressive disorder OR depressive symptoms OR depressive syndrome) AND (Serotonin transporter OR 5-hydroxytryptamine transporter OR 5-HT transporter OR 5-HTT OR SLC6A4 OR 5-HTT gene-linked polymorphic region OR 5-HTTLPR) AND (polymorphism OR SNP OR Variant). In addition, hand search was conducted for relevant studies from reference lists.

\section{Data extraction}

Two authors were responsible for data extraction of the enrolled articles. They independently extracted necessary information in accordance with a standard table including: surname of first author, publication year, country and ethnicity, study design, diagnostic criteria for depression, genotyping method, sample size, genotype distributions in depressed and non-depressed CHD patients, the value of adjusted OR and its $95 \% \mathrm{CI}$ and adjusted variables.

\section{Statistical analysis}

The correlation strength was assessed by odds ratios and the corresponding 95\% confidence intervals (95\% CIs). For crude data, we calculated ORs and their 95\%CIs according to the allele comparison (S vs. L), homozygote comparison (SS vs. LL), heterozygote comparison (LS vs. LL), dominant model (LS + SS vs. LL), and recessive model (SS vs. LL + LS). For adjusted data, the relevant ORs and their $95 \% \mathrm{CIs}$ were able to be found in the article. We measured heterogeneity assumption by Cochrane $Q$ test and $\mathrm{I}^{2}$ statistic [15]. Random-effects model $\left(P<0.10\right.$ or $\left.\mathrm{I}^{2}>50 \%\right)$ or fixed-effect model $(P>0.10$ and $\mathrm{I}^{2}<50 \%$ ) would be used according to the significant heterogeneity.

Subgroup analyses were performed based on ethnicity and major depressive disorder. All above analyses were performed using the Review Manager 5.3 software. In addition, Egger's tests [16] and funnel plots were used for assessing potential publication bias by STATA 12.0 software. 


\section{Results}

\section{Characteristics of included studies}

A total of 85 records was yielded and finally 6 observational studies [11, 12, 17-20] were selected in this metaanalysis, involving 1780 CHD comorbid depression (CHD-D) patients and 2712 CHD without depression (CHD-nD) patients. A flow diagram of the process of study selection was presented in Fig. 1.

Of them, there were two case-control studies conducted in China [12, 17]; two prospective observational studies conducted in Japan [11] and Korea [20], respectively. Another two studied patients enrolled in the same prospective observational study in America [18, 19], but one of the studies focused on major depressive disorder [19]. Regarding the prospective studies, we only extracted the baseline genotype data for analysis. Indeed, they can be deemed as case-control studies in this meta-analysis. The study by Kim et al. [20] investigated both any and major depressive disorder. Finally, five studies $[11,12,17,18,20]$ were involved in overall analysis and two studies $[19,20]$ involved in investigating major depressive disorder. Furthermore, five studies $[11,12,17,18,20]$ provided the distribution of the polymorphism in depressed and non-depressed CHD patients as well as adjusted ORs and their 95\%CIs. No deviation from the Hardy-Weinberg equilibrium was observed for any genotype. Blood samples were collected and polymerase chain reaction (PCR)-based genotyping was used to detect the polymorphism in all eligible studies. Detailed information of characteristics of included studies is summarized in Tables 1 and 2 .

\section{Overall analyses}

The pooled results from crude data indicated there was remarkable association between 5-HTTLPR polymorphism and depression risk in CHD patients under all genetic models [S vs. $\mathrm{L}$ : $\mathrm{OR}=1.31,95 \% \mathrm{CI}=1.07-1.60$ (Fig. 2); $\mathrm{SS}$ vs. $\mathrm{LL}: \mathrm{OR}=1.73,95 \% \mathrm{CI}=1.12-2.67 ; \mathrm{LS}$ vs. $\mathrm{LL}: \mathrm{OR}=1.47$, $95 \% \mathrm{CI}=1.13-1.92 ; \mathrm{LS}+\mathrm{SS}$ vs. LL: $\mathrm{OR}=1.62,95 \% \mathrm{CI}=1.25-$ 2.09; SS vs. $\mathrm{LL}+\mathrm{LS}: \mathrm{OR}=1.33,95 \% \mathrm{CI}=1.02-1.74]$ (Table 3). The results of adjusted data strengthened the association between 5-HTTLPR polymorphism and depression risk in CHD patients (SS vs. $\mathrm{LL}$ : $\mathrm{OR}=1.89,95 \% \mathrm{CI}=1.28-2.80$; $\mathrm{LS}$ vs. $\mathrm{LL}: \mathrm{OR}=1.69,95 \% \mathrm{CI}=1.14-2.51 ; \mathrm{LS}+\mathrm{SS}$ vs. $\mathrm{LL}: \mathrm{OR}=$ $1.80,95 \% \mathrm{CI}=1.25-2.59$ ) (Fig. 3).

\section{Subgroup analyses}

The subgroup analyses results were similar to that of the overall analysis. Significant associations were observed in Asians [ $\mathrm{S}$ vs. $\mathrm{L}$ : $\mathrm{OR}=1.33,95 \% \mathrm{CI}=$ $1.03-1.72$; SS vs. $\mathrm{LL}+\mathrm{LS}: \mathrm{OR}=1.39$, $95 \% \mathrm{CI}=1.01-$

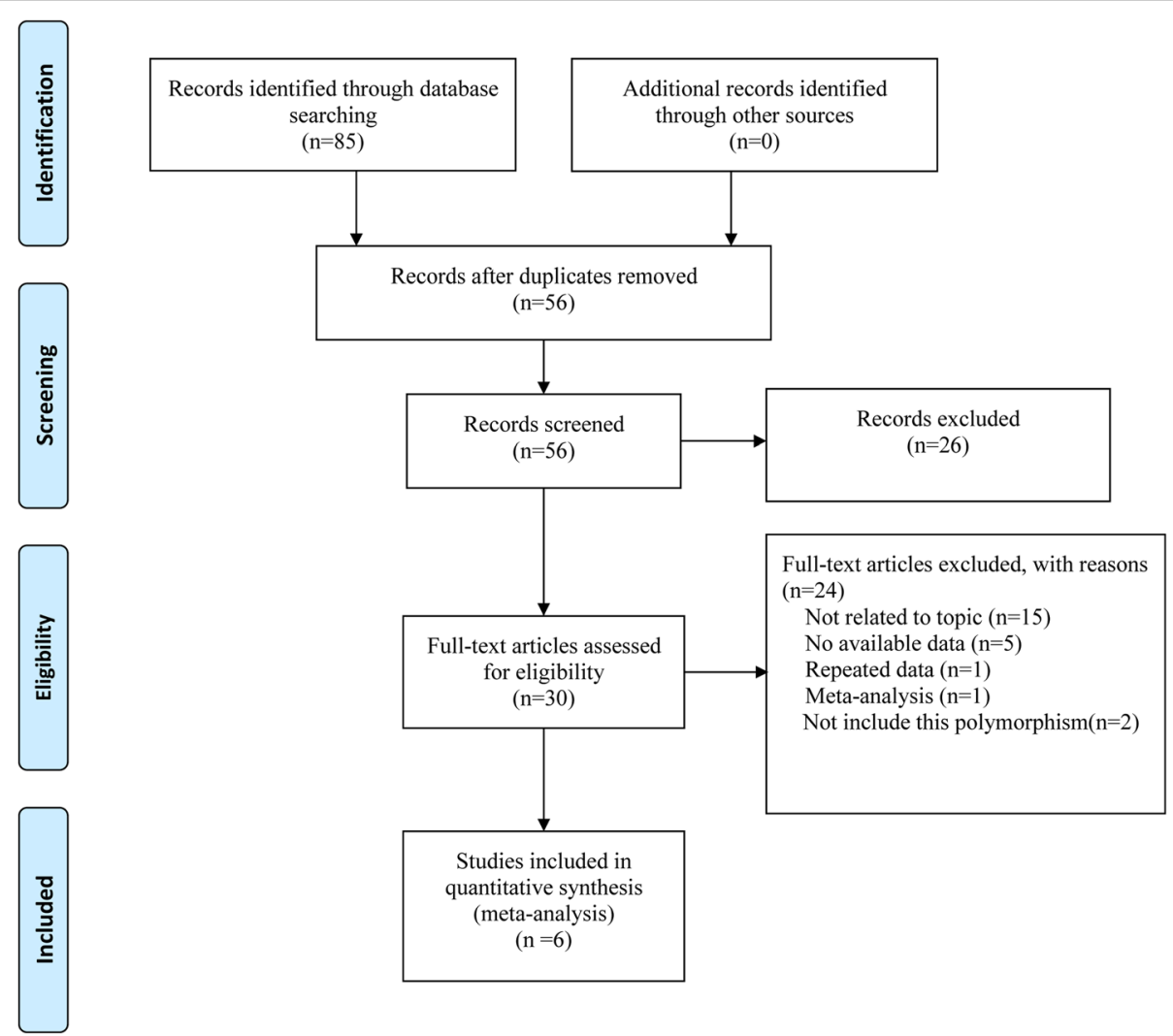

Fig. 1 The flow diagram of study selection 
Table 1 Characteristics and unadjusted data of included studies

\begin{tabular}{|c|c|c|c|c|c|c|c|c|c|c|c|c|c|}
\hline \multirow[t]{2}{*}{ Reference } & \multirow{2}{*}{$\begin{array}{l}\text { Country } \\
\text { (Ethnicity) }\end{array}$} & \multirow{2}{*}{$\begin{array}{l}\text { Diagnosticcriteria for } \\
\text { depression }\end{array}$} & \multirow{2}{*}{$\begin{array}{l}\text { Severity of } \\
\text { depression }\end{array}$} & \multicolumn{2}{|c|}{ Sample size } & \multicolumn{3}{|c|}{ CHD-D } & \multicolumn{3}{|c|}{ CHD-nD } & \multirow{2}{*}{$\begin{array}{l}\text { Genotype } \\
\text { method }\end{array}$} & \multirow[t]{2}{*}{ HWE } \\
\hline & & & & CHD-D & CHD-nD & $\mathrm{S} / \mathrm{S}$ & $\mathrm{L} / \mathrm{S}$ & $\mathrm{L} / \mathrm{L}$ & $S / S$ & L/S & $\mathrm{L} / \mathrm{L}$ & & \\
\hline Nakatani 2005 [11] & $\begin{array}{l}\text { Japan } \\
\text { (Asian) }\end{array}$ & SDS & Depression & 861 & 942 & 552 & 281 & 28 & 592 & 298 & 52 & PCR & Yes \\
\hline Cao 2007 [12] & $\begin{array}{l}\text { China } \\
\text { (Asian) }\end{array}$ & CCMD-3; SDS; HAMD & Depression & 153 & 171 & 95 & 46 & 12 & 96 & 67 & 8 & PCR & Yes \\
\hline Xia 2006 [17] & $\begin{array}{l}\text { China } \\
\text { (Asian) }\end{array}$ & CCMD-3; SDS & Depression & 70 & 70 & 35 & 25 & 10 & 16 & 32 & 22 & PCR & Yes \\
\hline Otte 2007 [18] & $\begin{array}{l}\text { America } \\
\text { (White) }\end{array}$ & $\begin{array}{l}\text { Interviews applying for DSM-IV } \\
\text { criteria. }\end{array}$ & Depression & 126 & 431 & 24 & 73 & 29 & 72 & 214 & 145 & PCR & Yes \\
\hline Kangelaris 2010 [19] & $\begin{array}{l}\text { America } \\
\text { (Mixed) }\end{array}$ & $\begin{array}{l}\text { Interviews applying for DSM-IV } \\
\text { criteria. }\end{array}$ & MDD & 192 & 678 & 35 & 102 & 55 & 137 & 314 & 227 & $P C R$ & Yes \\
\hline \multirow[t]{2}{*}{ Kim 2015 [20] } & \multirow[t]{2}{*}{ Korea (Asian) } & \multirow{2}{*}{$\begin{array}{l}\text { Interviews applying for DSM-IV } \\
\text { criteria. }\end{array}$} & Depression & 378 & 591 & 239 & 121 & 18 & 329 & 219 & 43 & PCR & \multirow[t]{2}{*}{ Yes } \\
\hline & & & MDD & 177 & 591 & 119 & 53 & 5 & 329 & 219 & 43 & PCR & \\
\hline
\end{tabular}

CHD-D coronary heart disease comorbid depression, CHD-nD coronary heart disease without depression; Mixed,White, African American, Asian, Latino, Other; HWE Hardy-Weinberg equilibrium, $P C R$ Polymerase Chain Reaction

SDS The Zung Self-rating Depression Scale, HAMD Hamilton Depression Scale, DSM-IV Diagnostic and Statistical Manual of Mental Disorders, 4th Edition

1.91] and Whites [LS vs. LL: $\mathrm{OR}=1.71,95 \% \mathrm{CI}=$ $1.06-2.75$; $\mathrm{LS}+\mathrm{SS}$ vs. $\mathrm{LL}: \mathrm{OR}=1.70,95 \% \mathrm{CI}=1.07-$ 2.69]. Statistical association between 5-HTTLPR polymorphism and major depressive disorder in CHD patients was also observed [LS vs. LL: OR = $1.43,95 \% \mathrm{CI}=1.01-2.02]$. All the results are presented in Table 3.

\section{Publication bias}

In this meta-analysis, no evidence of publication bias was detected under any genetic models assessed by Egger's test (S vs. L: $p=0.196$; SS vs. LL: $p=0.962$; LS vs. LL: $p=0.195$; $\mathrm{LS}+\mathrm{SS}$ vs. LL: $p=0.543$; SS vs. LL + LS: $p=0.151$ ) and funnel plots (Fig. 4).

\section{Discussion}

In accordance with Nakatani [11], Xia [17], Otte [18], and Kim [20], this meta-analysis elucidates that $S$ allele (including SS and SL) is related with depression in CHD patients, especially major depression. Otherwise, subgroup analysis explains that $\mathrm{S}$ allele associates with both Asian and White. The implications are worth special considerations.

As far as we are concerned, depression and CHD are not isolated form each other, but interrelated with each other essentially. In the light of the current researches, we hypothesis the potential mechanisms under 5-HTTLPR, depression and CHD as follows:

Firstly, CHD patients with $\mathrm{S}$ allele present expression reduction of 5 -HTT in the cell membrane inducing decreased reuptake of 5-HT. Moreover, the total concentration of 5-HT in synaptic cleft reduces in virtue of organic cation transporter (OCT) [21], which has been proved to reuptake 5 -HT in compensation of 5-HTT reduction. Consequently, depressive symptoms develop due to the deficiency of 5-HT, which could be treated with selective serotonin reuptake inhibitor (SSRI) by targeting at 5-HTT. In this meta-analysis, we indicate the association of $\mathrm{S}$ allele and depression, notably major depression. The major strength of this study is that we consider adjusted data and severity of depression. According to Diagnostic and Statistical Manual of Mental Disorders Fifth Edition (DSM-5), depressive disorders

Table 2 Adjustment and adjusted data of included studies

\begin{tabular}{|c|c|c|c|c|}
\hline Reference & Ethnicity & Gentic models & $\mathrm{OR}(95 \% \mathrm{Cl})$ & Adjustment \\
\hline \multirow[t]{3}{*}{ Nakatani 2005 [11] } & \multirow[t]{3}{*}{ Asian } & SS vs LL & $1.97(1.16-3.35)$ & \multirow{3}{*}{$\begin{array}{l}\text { age, sex, diabetes mellitus, hypertension, hyperlipidemia, } \\
\text { smoking, a history of Ml, a Killip class of }>\| l \text {, anterior infarction } \\
\text { reperfusion therapy, and treatment with antiplatelet agents, } \\
\text { angiotensin-converting enzyme inhibitors, or beta-blockers. }\end{array}$} \\
\hline & & LS vs LL & $2.02(1.17-3.51)$ & \\
\hline & & $L S+S S$ vS LL & $2.19(1.21-3.98)$ & \\
\hline Otte 2007 [18] & White & $L S+S S$ vS LL & $1.6(1.0-2.5)$ & age, sex \\
\hline [17] & Asian & SS vs LL + LS & $2.048(1.132-3.704)$ & hypertension, smoking, diabetes, BMI, TC, TG, LDL-C, HDL-C, \\
\hline Cao 2007 [12] & Asian & S vs L & $2.34(1.38-3.98)$ & age, sex, smoking, diabetes, education, hypertension, TC, TG \\
\hline \multirow[t]{2}{*}{ Kim 2015 [20] } & \multirow[t]{2}{*}{ Asian } & SS vs LL & $1.80(1.03-3.30)$ & \multirow{2}{*}{$\begin{array}{l}\text { sex, education, living alone, housing, current employment, } \\
\text { hypertension, diabetes, and current smoking. }\end{array}$} \\
\hline & & LS vs LL & $1.39(0.79-2.49)$ & \\
\hline
\end{tabular}




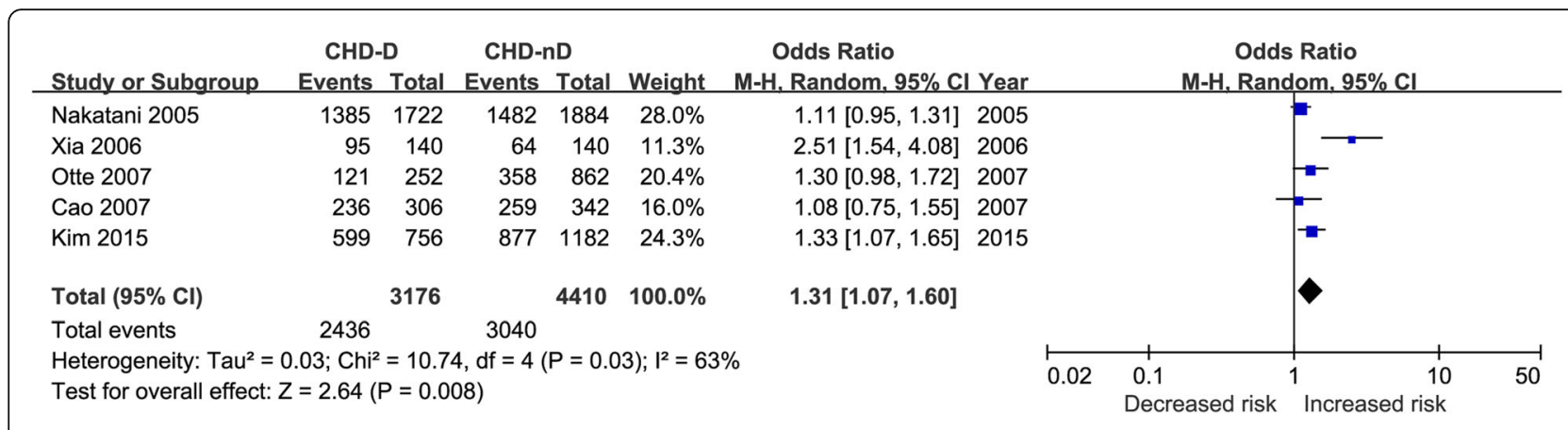

Fig. 2 Forest plot of overall analysis in allele comparison. CHD-D, coronary heart disease comorbid depression; CHD-nD, coronary heart disease without depression; $\mathrm{Cl}$, confidence intervals

involve major depressive disorder, persistent depressive disorder, depressive disorder due to another medical condition et al. [22]. Two studies from Kangelaris [19] and kim [20] respectively, focus on major depression, drawing the identical conclusion that $\mathrm{S}$ allele increases the risk of major depression in CHD patients.
Secondly, 5-HT, as a neurotransmitter in CNS, transduces biological signal via activating 5 -HT receptors located in postsynaptic membrane. Notably $5-\mathrm{HT}_{2 \mathrm{~A}}$ receptor (5$\mathrm{HT}_{2 \mathrm{~A}} \mathrm{R}$ ) is a dominant receptor of serotonin receptor family. Our former researches have demonstrated the relationship between $5-\mathrm{HT}_{2 \mathrm{~A}} \mathrm{R}$ and myocardial infarction combined with

Table 3 Results of overall and subgroup analyses

\begin{tabular}{|c|c|c|c|c|c|}
\hline \multirow{2}{*}{$\begin{array}{l}\text { Overall and subgroup } \\
\text { analysis }\end{array}$} & \multirow[t]{2}{*}{ Studies } & \multicolumn{2}{|c|}{ Test of association } & \multicolumn{2}{|c|}{ Test of association } \\
\hline & & $\overline{\mathrm{OR}(95 \% \mathrm{Cl})}$ & $\overline{P \text {-value }}$ & $\overline{1^{2}}$ & $\mathrm{Ph}$ \\
\hline \multicolumn{6}{|l|}{ S vs. L } \\
\hline Total & 5 & $1.31(1.07-1.60)$ & 0.008 & $63 \%$ & 0.03 \\
\hline Asian & 4 & $1.33(1.03-1.72)$ & 0.03 & $72 \%$ & 0.01 \\
\hline White & 1 & $1.30(0.98-1.72)$ & 0.07 & NA & NA \\
\hline Major depressive disorder & 2 & $1.29(0.86-1.94)$ & 0.22 & $79 \%$ & 0.03 \\
\hline \multicolumn{6}{|l|}{ SS vs. LL } \\
\hline Total & 5 & $1.73(1.12-2.67)$ & 0.01 & $53 \%$ & 0.08 \\
\hline Asian & 4 & $1.75(0.97-3.13)$ & 0.06 & $65 \%$ & 0.04 \\
\hline White & 1 & $1.67(0.91-3.07)$ & 0.10 & NA & NA \\
\hline Major depressive disorder & 2 & $1.67(0.58-4.83)$ & 0.34 & $76 \%$ & 0.04 \\
\hline \multicolumn{6}{|l|}{ LS vs. LL } \\
\hline Total & 5 & $1.47(1.13-1.92)$ & 0.005 & $40 \%$ & 0.15 \\
\hline Asian & 4 & $1.27(0.77-2.10)$ & 0.35 & $51 \%$ & 0.11 \\
\hline White & 1 & $1.71(1.06-2.75)$ & 0.03 & NA & NA \\
\hline Major depressive disorder & 2 & $1.43(1.01,2.02)$ & 0.04 & $0 \%$ & 0.41 \\
\hline \multicolumn{6}{|l|}{ LS + SS vs. LL } \\
\hline Total & 5 & $1.62(1.25-2.09)$ & 0.0002 & $38 \%$ & 0.17 \\
\hline Asian & 4 & $1.52(0.93-2.47)$ & 0.09 & $53 \%$ & 0.09 \\
\hline White & 1 & $1.70(1.07-2.69)$ & 0.02 & NA & NA \\
\hline Major depressive disorder & 2 & $1.62(0.79-3.30)$ & 0.19 & $56 \%$ & 0.13 \\
\hline \multicolumn{6}{|l|}{ SS vs. LL + LS } \\
\hline Total & 5 & $1.33(1.02-1.74)$ & 0.03 & $62 \%$ & 0.03 \\
\hline Asian & 4 & $1.39(1.01-1.91)$ & 0.05 & $71 \%$ & 0.02 \\
\hline White & 1 & $1.17(0.70-1.96)$ & 0.54 & NA & NA \\
\hline Major depressive disorder & 2 & $1.21(0.66-2.22)$ & 0.54 & $80 \%$ & 0.03 \\
\hline
\end{tabular}

OR odds ratio, $\mathrm{Cl}$ confidence intervals, NA not applicable 


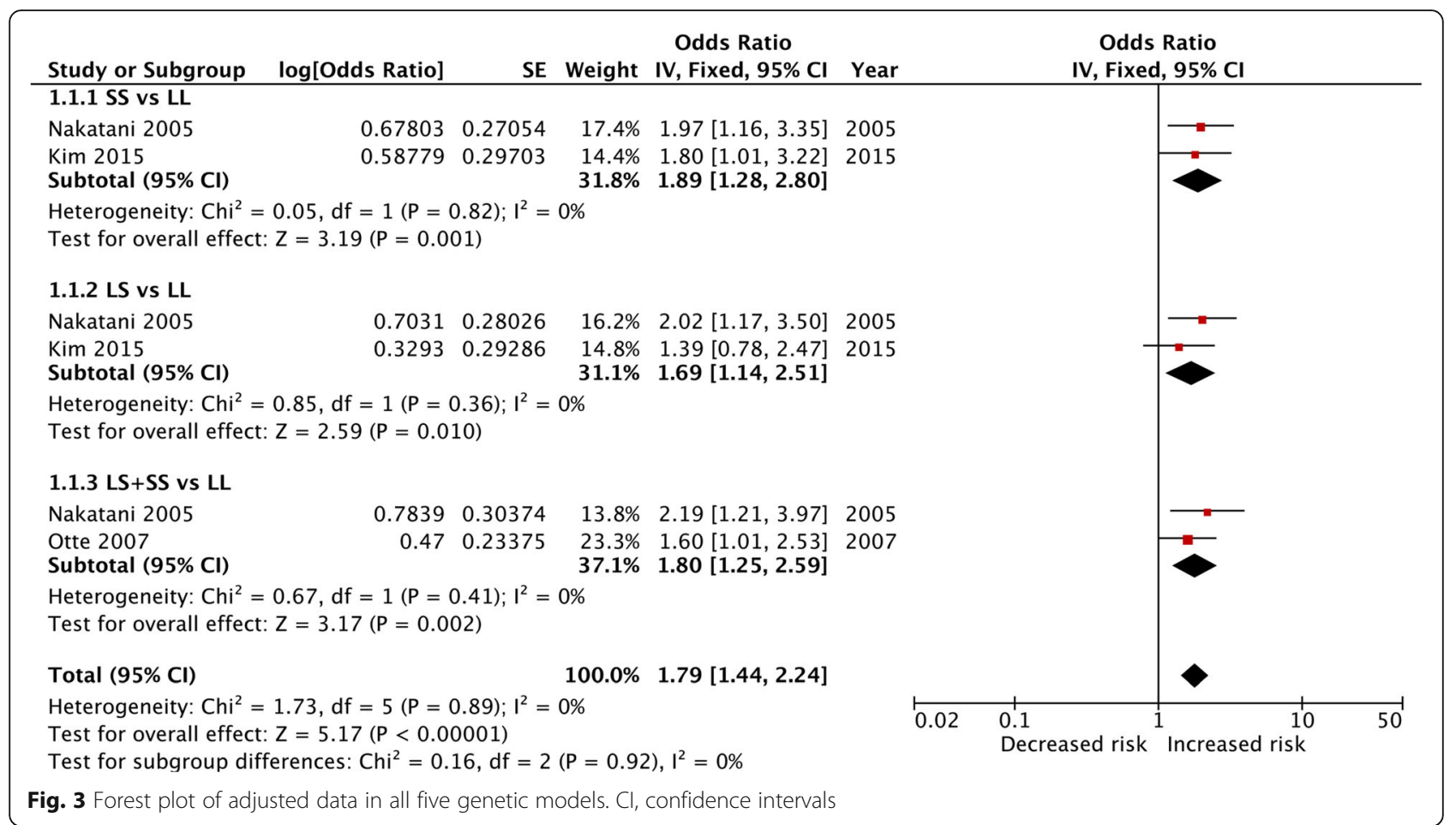

depression [23]. Moreover, several studies reported the important role of $5-\mathrm{HT}_{2 \mathrm{~A}} \mathrm{R}$ gene polymorphisms (-1438 A/G and $102 \mathrm{~T} / \mathrm{C}$ ) in psychiatric disorders [24]. While a metaanalysis didn't find significant association between - $1438 \mathrm{~A} /$ $\mathrm{G}$ polymorphism of $5-\mathrm{HT}_{2 \mathrm{~A}} \mathrm{R}$ and major depressive disorders [25]. Therefore, more original researches should be done to further explore the relationship.

Thirdly, it is widely acknowledged that ethnicity is associated with genetic polymorphism [26]. This meta- analysis involves Asians (from China [12, 17], Japan [11], and Korea [20]) and Whites (from America [18, 19]). To explore the relationship between ethnicity and 5HTTLPR polymorphism, we performed the subgroup analyses based on ethnicity. The results showed 5HTTLPR polymorphism and depression risk in CHD patients of both Asians and Whites. (Table 3).

In addition, we have to admit the limitations in this meta-analysis. Firstly, only six original researches are

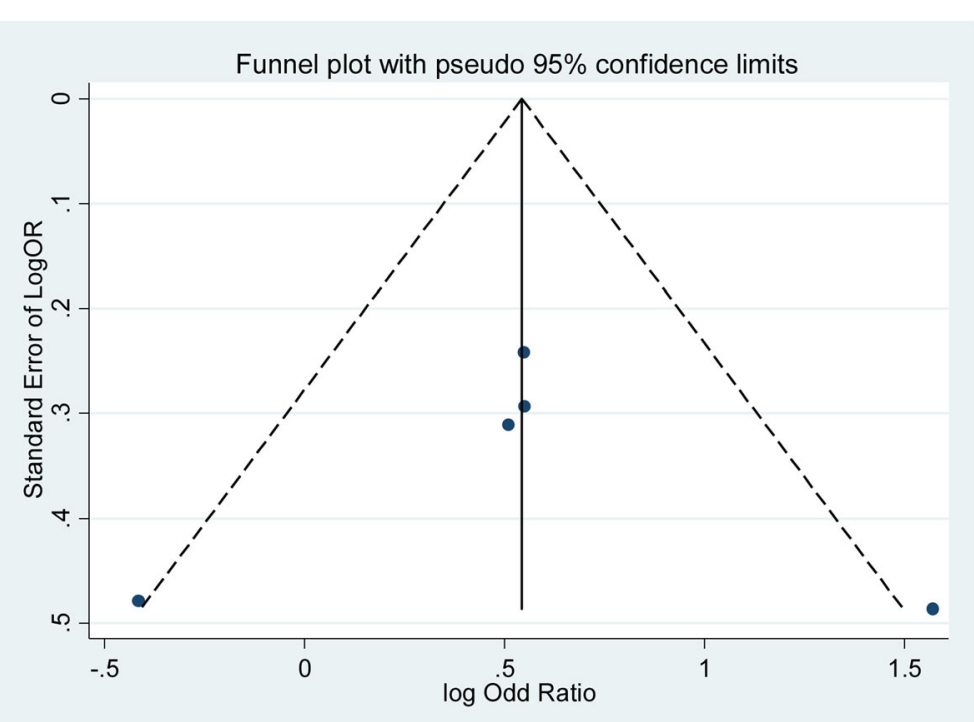

Fig. 4 Funnel plot of overall analysis in homozygote comparison. OR, odds ratio 
eligible for this meta-analysis, making the results not roust enough. Hence, we are expecting for more original studies conducted on this topic; Secondly, it would be better to focus on sex specificity for the differences of 5-HT synthesis rate between female and male. However, the current data collected from the studies don't support sex subgroup analysis; Thirdly, for sake of exploring the possible mechanisms, the relevant factors involving 5-HT, 5-HTT should be detected. While no studies had performed it.

\section{Conclusion}

In conclusion, $\mathrm{CHD}$ patients with $\mathrm{S}$ allele are more vulnerable to depression, even major depression. However, we still need more evidence to prove the its specifity and sensitivity before it could be adapted to clinical diagnose. We believe that, in the near future, we could predict depression in CHD patients before they present any clinical symptoms just by extracting a few blood for 5-HTTLPR detection.

\begin{abstract}
Abbreviations
CHD: Coronary heart disease; 5-HTTLPR: Serotonin transporter gene-linked polymorphic region; CNS: Central nervous system; CBM: Chinese BioMedical literature; CNKI: Chinese national knowledge infrastructure; ORs: Odds ratios; 95\%Cls: 95\% confidence intervals; 5-HT: Serotonin; 5-HTT: Serotonin transporter; PCR: Polymerase chain reaction; $H_{2} \mathrm{~A}$ : Serotonin receptor $2 \mathrm{~A}$; DSM-5: Diagnostic and statistical manual of mental disorders fifth edition; CDIS-IV: Computerized diagnostic interview schedule; MINI: MINI-international neuropsychiatric interview; SDS: Zung self-rating depression scale
\end{abstract}

\section{Acknowledgements}

None.

\section{Authors' contributions}

MYL designed the study. LZZ and MJZ wrote the manuscript. XTZ revised the manuscript. DFH and JYL searched the eligible studies, extracted the data, and did statistical analysis. The author(s) read and approved the final manuscript.

\section{Funding}

National Key Basic Research Program of China (973 program; No. 2015CB554402) and National Academy of Innovation Strategy (Grant No. 2019ys1-4-4-8). They contribute to the design of this meta-analysis.

\section{Availability of data and materials}

The data can be obtained from the corresponding author under reasonable request.

\section{Ethics approval and consent to participate}

Not Applicable.

\section{Consent for publication}

Not Applicable.

\section{Competing interests}

The authors declare that they have no competing interests.

\section{Author details}

'Department of Cardiology, Beijing Anzhen Hospital Affiliated to Capital Medical University, No. 2 Anzhen Road, Chaoyang District, Beijing 100029 China. ${ }^{2}$ Center for Evidence-Based and Translational Medicine, Zhongnan Hospital of Wuhan University, Wuhan 430071, Hubei, China. ${ }^{3}$ Center for Evidence-Based and Translational Medicine, Wuhan University, Wuhan 430071, Hubei, China. ${ }^{4}$ Department of Cardiology, The First Affiliated Hospital of Henan University, Kaifeng 475001, Henan, China.
Received: 7 September 2019 Accepted: 10 March 2020

Published online: 18 March 2020

\section{References}

1. Berry EM. The role of the sociotype in managing chronic disease: integrating bio-psycho-sociology with systems biology. Med Hypotheses. 2011;77(4):610-3.

2. Wulsin $L R$, Singal $B M$. Do depressive symptoms increase the risk for the onset of coronary disease? A systematic quantitative review. Psychosom Med. 2003;65(2):201-10.

3. Bondy B. Common genetic factors for depression and cardiovascular disease. Dialogues Clin Neurosci. 2007;9(1):19-28.

4. Lichtman JH, Froelicher ES, Blumenthal JA, Carney RM, Doering LV, FrasureSmith N, Freedland KE, Jaffe AS, Leifheit-Limson EC, Sheps DS, et al. Depression as a risk factor for poor prognosis among patients with acute coronary syndrome: systematic review and recommendations: a scientific statement from the American Heart Association. Circulation. 2014;129(12):1350-69.

5. Phillips-Bute B, Mathew JP, Blumenthal JA, Morris RW, Podgoreanu MV, Smith M, Stafford-Smith M, Grocott HP, Schwinn DA, Newman MF. Relationship of genetic variability and depressive symptoms to adverse events after coronary artery bypass graft surgery. Psychosom Med. 2008; 70(9):953-9.

6. Ni W, Watts SW. 5-hydroxytryptamine in the cardiovascular system: focus on the serotonin transporter (SERT). Clin Exp Pharmacol Physiol. 2006:33(7):575-83.

7. Risch SC, Nemeroff CB. Neurochemical alterations of serotonergic neuronal systems in depression. J Clin Psychiatry. 1992:53(Suppl):3-7.

8. Lesch KP, Bengel D, Heils A, Sabol SZ, Greenberg BD, Petri S, Benjamin J, Muller CR, Hamer DH, Murphy DL. Association of anxiety-related traits with a polymorphism in the serotonin transporter gene regulatory region. Science (New York, NY). 1996;274(5292):1527-31.

9. Caspi A, Sugden K, Moffitt TE, Taylor A, Craig IW, Harrington H, McClay J, Mill J, Martin J, Braithwaite A, et al. Influence of life stress on depression: moderation by a polymorphism in the $5-\mathrm{HTT}$ gene. Science (New York, NY). 2003;301(5631):386-9.

10. Ramasubbu R, Tobias R, Buchan AM, Bech-Hansen NT. Serotonin transporter gene promoter region polymorphism associated with poststroke major depression. J Neuropsychiatry Clin Neurosci. 2006;18(1):96-9.

11. Nakatani D, Sato H, Sakata Y, Shiotani I, Kinjo K, Mizuno H, Shimizu M, Ito H, Koretsune $Y$, Hirayama $A$, et al. Influence of serotonin transporter gene polymorphism on depressive symptoms and new cardiac events after acute myocardial infarction. Am Heart J. 2005;150(4):652-8.

12. Cao MQ: Study on the relationship between correlative polymorphism and coronary heart disease with depressive episode and the syndome of blood stasis/phlegm stagnation of this disorder. Thesis. Zhongnan University; 2007:1-24.

13. Bozzini S, Gambelli P, Boiocchi C, Schirinzi S, Falcone R, Buzzi P, Storti C, Falcone C. Coronary artery disease and depression: possible role of brainderived neurotrophic factor and serotonin transporter gene polymorphisms. Int J Mol Med. 2009;24(6):813-8.

14. Moher D, Liberati A, Tetzlaff J, Altman DG. Preferred reporting items for systematic reviews and meta-analyses: the PRISMA statement. Open Med. 2009:3(3):e123-30

15. Huedo-Medina TB, Sanchez-Meca J, Marin-Martinez F, Botella J. Assessing heterogeneity in meta-analysis: Q statistic or 12 index? Psychol Methods. 2006;11(2):193-206.

16. Egger M, Davey Smith G, Schneider M, Minder C. Bias in meta-analysis detected by a simple, graphical test. BMJ (Clinical research ed). 1997; 315(7109):629-34

17. Xia D, Cao J, Xu J, Yo W, Li C, Cai L, Guo Q, Dang Q. Association of Serotonin Transporter Gene Polymorphism and Depressive Disorder in patients with coronary heart disease. Tianjin Med J. 2006;34(11):774-7.

18. Otte C, McCaffery J, Ali S, Whooley MA. Association of a serotonin transporter polymorphism (5-HTTLPR) with depression, perceived stress, and norepinephrine in patients with coronary disease: the heart and soul study. Am J Psychiatry. 2007;164(9):1379-84.

19. Kangelaris KN, Vittinghoff E, Otte C, Na B, Auerbach AD, Whooley MA. Association between a serotonin transporter gene variant and hopelessness among men in the heart and soul study. J Gen Intern Med. 2010;25(10):1030-7.

20. Kim JM, Stewart R, Kang HJ, Bae KY, Kim SW, Shin IS, Hong YJ, Ahn Y, Jeong $\mathrm{MH}$, Park SW, et al. Serotonergic genes and depressive disorder in acute 
coronary syndrome: the Korean depression in ACS (K-DEPACS) study. Eur Neuropsychopharmacol. 2015;25(6):882-8.

21. Schmitt A, Mössner R, Gossmann A, Fischer IG, Gorboulev V, Murphy DL, Koepsell H, Lesch KP. Organic cation transporter capable of transporting serotonin is up-regulated in serotonin transporter-deficient mice. J Neurosci Res. 2003;71(5):701-9.

22. Segal D L MMA, Coolidge F L . : Diagnostic and Statistical Manual of Mental Disorders, Fifth Edition (DSM-5). SAGE Encyclopedia of Abnormal and Clinical Psychology 2017.

23. Liu MY, Ren YP, Wei WL, Tian GX, Li G. Changes of serotonin (5-HT), 5-HT2A receptor, and 5-HT transporter in the Sprague-Dawley rats of depression myocardial infarction and myocardial infarction co-exist with depression. Chin Med J. 2015;128(14):1905-9.

24. Serretti A, Drago A, De Ronchi D. HTR2A gene variants and psychiatric disorders: a review of current literature and selection of SNPs for future studies. Curr Med Chem. 2007;14(19):2053-69.

25. Jin C, Xu W, Yuan J, Wang G, Cheng Z. Meta-analysis of association between the $-1438 \mathrm{~A} / \mathrm{G}$ (rs6311) polymorphism of the serotonin $2 \mathrm{~A}$ receptor gene and major depressive disorder. Neurol Res. 2013;35(1):7-14.

26. Chen Y, Liao Y, Sun S, Lin F, Li R, Lan S, Zhao X, Qin J, Rao S. Stratified metaanalysis by ethnicity revealed that ADRB3 Trp64Arg polymorphism was associated with coronary artery disease in Asians, but not in Caucasians. Medicine. 2020;99(4):e18914.

\section{Publisher's Note}

Springer Nature remains neutral with regard to jurisdictional claims in published maps and institutional affiliations.

Ready to submit your research? Choose BMC and benefit from:

- fast, convenient online submission

- thorough peer review by experienced researchers in your field

- rapid publication on acceptance

- support for research data, including large and complex data types

- gold Open Access which fosters wider collaboration and increased citations

- maximum visibility for your research: over $100 \mathrm{M}$ website views per year

At BMC, research is always in progress.

Learn more biomedcentral.com/submissions 